\title{
Development and evaluation of biomass-based alternative charcoal
}

\author{
Adeshina Fadeyibi, Kehinde Raheef Adebayo, Taiye Mayowa Obafemi, Abiodun Samson Olubo, Rasheed \\ Amao Busari, Mohammed Gana Yisa
}

Department of Food and Agricultural Engineering, Faculty of Engineering and Technology, Kwara State University, Malete, Kwara State, Nigeria

\begin{abstract}
Environmental issues resulting from production and application of wood charcoal can be addressed by using biomass briquettes as alternative. This research was undertaken to develop and evaluate briquette from jatropha, groundnut and melon seed residues. Samples of the briquette were formed from mixtures of $0.32-0.39 \mathrm{~kg}$ carbonised residues, $0.30-0.40 \mathrm{~kg}$ starch and $0.02-$ $0.04 \mathrm{~kg}$ water. Physical and mechanical properties of the briquette samples including calorific value, bulk density and breaking force were determined using standard methods. Box-Bekhen Design Methodology was used to determine the optimum briquette blend. The results showed that the optimal briquette blend gave values of $4711.87 \mathrm{kcal} \cdot \mathrm{kg}^{-1}$ calorific value, $282.59 \mathrm{~kg} \mathrm{~m}^{-3}$ bulk density and $1.36 \mathrm{kN}$ breaking force, with a desirability index of $61.5 \%$. A comparative analysis of the properties of the optimal briquette with that of a wood charcoal indicates no significant difference $(\mathrm{P}<0.05)$. This implies that the briquette can serve as an alternative energy source for cooking in rural communities.
\end{abstract}

Correspondence: Adeshina Fadeyibi, Department of Food and Agricultural Engineering, Faculty of Engineering and Technology, Kwara State University, Malete, P.M.B. 1530 Ilorin, Kwara State, Nigeria. Tel.: +2347034867681 .

E-mail: adeshina.fadeyibi@kwasu.edu.ng

Key words: Agricultural residues; briquette; briquette properties; feedstock blending optimisation; cooking energy.

Acknowledgements: the authors would like to thank the Tertiary Education Trust Fund (TETFund) of the Federal Ministry of Education, for providing financial support for this research, through the Kwara State University, Malete, Nigeria (KWASUNGR/CSP/171117/ VOL4/TETF/0044).

Received for publication: 23 November 2019.

Accepted for publication: 20 May 2020.

(C) Copyright: the Author(s), 2020

Licensee PAGEPress, Italy

Journal of Agricultural Engineering 2020; LI:1032

doi:10.4081/jae.2020.1032

This article is distributed under the terms of the Creative Commons Attribution Noncommercial License (by-nc 4.0) which permits any noncommercial use, distribution, and reproduction in any medium, provided the original author(s) and source are credited.

\section{Introduction}

Charcoal is the principal source of energy for cooking in rural communities because it is cheap and readily available (Stout et al., 1985). The production of wood charcoal involves carbonisation or charring of wood at a very high temperature, usually in the range of $200-300^{\circ} \mathrm{C}$, to form carbon. The wood charcoal has found numeruous commertial applications, especially in the alloy and steel industries; and can create jobs when traded as market commodities. The product however, is usually associated with both short and long term challenges (Boersema and Reijnders, 2009). For instance, the use of wood charcoal can cause health issue associated with respiration because of the pollution effect, and this may lead to heart failure in the short term. It may also result in the extinction of wild lives, thereby affecting the general stability of the ecosystem in the long term (Antal and Grønli, 2003; Adam, 2009). Moreover, the era of the fossil fuel is fast declining, petroleum and its products will be the first to deplete followed by coal (Höök and Tang, 2013). The solution to this, however, lies in the use of renewable resources such as biomass energy. One type of biomass materials is the agricultural residues, which is obtained as a by-product of the processing of crops on the farm (Grella et al., 2014), industries and our homes (Bhattacharya et al., 2000).

Biomass residue presents alternative and important raw material for production of clean energy, thereby avoiding problems associated with the use of the wood charcoal (Ben-Iwo et al., 2016). The annual production capacity of some crops with high biomass energy potential in Nigeria and by extension in the world is typically presented in Table 1 (Ryu et al., 2006; Jamradloedluk and Wiriyaumpaiwong, 2007; Ben-Iwo et al., 2016). The heating values of the jatropha seed, melon seed and groundnut shells are well known to be higher than other available biomass sources. Hence, in order to maximize the energy potentials of the biomass, they can be transformed into briquettes for cooking energy utilisation (da Costa et al., 2004; Ahiduzzaman, 2007; Lucchini et al., 2014). However, despite the availability and higher energy potential of the Jatropha seed shells, groundnut shells and melon seed shells, there is no reported research on briquette production from the above mentioned raw materials. There is therefore the need to evaluate the potential huge energy presented by the products.

A lot of studies on the optimisation of briquette process variables have been undertaken in the past. For instance, the optimisation of the quality of briquette from the by-product of rice processing was reported by Ndindeng et al. (2015). The authors reported that the briquettes made from rice husk-bran-fibre and husk-bran has characteristics features desirable by consumers. Musabbikhah et al. (2017) studied the process optimisation of the heating values of the coconut shell using Taguchi method, and reported a $60 \%$ increase in the calorific value of the product with an increase in time and temperature. Kaur et al. (2017) optimised the production variables of briquettes from biomass residues and reported that 
best briquette ignites and burns at $12 \mathrm{sec}$ and $5 \mathrm{~min}$, respectively. Thoreson et al. (2014), in their separate investigations, studied the influence of densification process and materials properties on briquette quality. The authors reported that density of briquette increases with an increase in the force of compression and a decrease in the particle size of the constitute materials. Helwani et al. (2018) and Tumuluru et al. (2011) investigated the effects of process variables on the energy value and the strength of some biomass briquettes. Their studies revealed an increase in the calorific value and the strength with an increase in the process variables. However, despite all these research findings, there are no reported researches on the optimisation of the briquette blends made from jatropha seed shells, groundnut shells and melon seed shells. There is therefore the need to carry out a study on the optimisation of the briquette process variables in order to establish the best briquette blend for alternative energy application. The objective of this research therefore was to optimise the briquette process variables based on the physical and mechanical properties of the briquette samples including bulk density, force at break, burning rate and calorific value.

\section{Materials and methods}

Three different biomass residues, namely jatropha seed shells, groundnut shells and melon seed shells obtained from Idofian Farms Ilorin, Kwara State was used for this analysis. These are non-woody products commonly referred to herbaceous biomass according to the ISO standard specification for solid biofuels (ISO, 2014). The materials were transported to the National Centre for Agricultural Mechanisation (NCAM), where their particle sizes were reduced to approximately $20 \mathrm{~mm}$ diameter using a hammer mill. The residues were thereafter carbonised by burning in a ringshaped metal airtight container for $15 \mathrm{~min}$ to form carbonised samples of the residues. Briquette samples were prepared by blending $0.30-0.39 \mathrm{~kg}$ of the carbonised sample from each of the agricultural residues with $0.30-0.40 \mathrm{~kg}$ of starch, which was used as a binding agent, and $0.02-0.04 \mathrm{~kg}$ of water. A total of 27 samples of the briquette blends were obtained, as shown in Table 2 .

\section{Description of a briquetting press}

A dually operated screw press was designed and fabricated from

Table 1. Biomass energy potential of some common resources in Nigeria.

\begin{tabular}{|c|c|c|c|c|c|c|c|}
\hline Main resource & $\begin{array}{l}\text { Production } \\
\left(\times 10^{3} \text { tons }\right)\end{array}$ & $\begin{array}{l}\text { Biomass } \\
\text { residue }\end{array}$ & $\begin{array}{l}\text { Residue to } \\
\text { product ratio }\end{array}$ & $\begin{array}{c}\text { Moisture } \\
\text { content (\%) }\end{array}$ & $\begin{array}{l}\text { Total residue } \\
\text { (million tons) }\end{array}$ & $\begin{array}{l}\text { Lower heating } \\
\text { value (MJ kg-1) }\end{array}$ & $\begin{array}{c}\text { Residue } \\
\text { energy potential } \\
\text { (Petajoule) }\end{array}$ \\
\hline Rice & 3368.24 & $\begin{array}{l}\text { Straw } \\
\text { Husk }\end{array}$ & $\begin{array}{l}1.757 \\
0.200\end{array}$ & $\begin{array}{l}12.71 \\
2.370\end{array}$ & $\begin{array}{l}7.860 \\
1.190\end{array}$ & $\begin{array}{l}16.02 \\
19.33\end{array}$ & $\begin{array}{l}125.02 \\
23.000\end{array}$ \\
\hline Jatropha & 2722.00 & Shell & 0.510 & 8.900 & 3.000 & 17.5 & 37.270 \\
\hline Melon & 782.205 & Husk & 0.910 & 6.970 & 2.140 & 21.78 & 79.890 \\
\hline Soybean & 365.060 & $\begin{array}{l}\text { Straw } \\
\text { Pods }\end{array}$ & $\begin{array}{l}2.500 \\
1.000\end{array}$ & $\begin{array}{l}15.00 \\
15.00\end{array}$ & $\begin{array}{l}0.910 \\
0.370\end{array}$ & $\begin{array}{l}12.38 \\
12.38\end{array}$ & $\begin{array}{l}11.270 \\
4.5800\end{array}$ \\
\hline Cotton & 602.440 & Stalk & 3.743 & 12.00 & 2.250 & 18.61 & 41.870 \\
\hline Millet & 5170.45 & Straw & 1.750 & 15.00 & 9.050 & 12.38 & 89.630 \\
\hline Groundnut & 3799.25 & $\begin{array}{l}\text { Shells } \\
\text { Straw }\end{array}$ & $\begin{array}{l}0.477 \\
2.300\end{array}$ & $\begin{array}{l}8.200 \\
15.00\end{array}$ & $\begin{array}{l}1.810 \\
8.740\end{array}$ & $\begin{array}{l}15.66 \\
17.58\end{array}$ & $\begin{array}{l}28.350 \\
76.830\end{array}$ \\
\hline Sorghum & 7140.96 & Straw & 1.250 & 15.00 & 8.930 & 12.38 & 88.390 \\
\hline
\end{tabular}

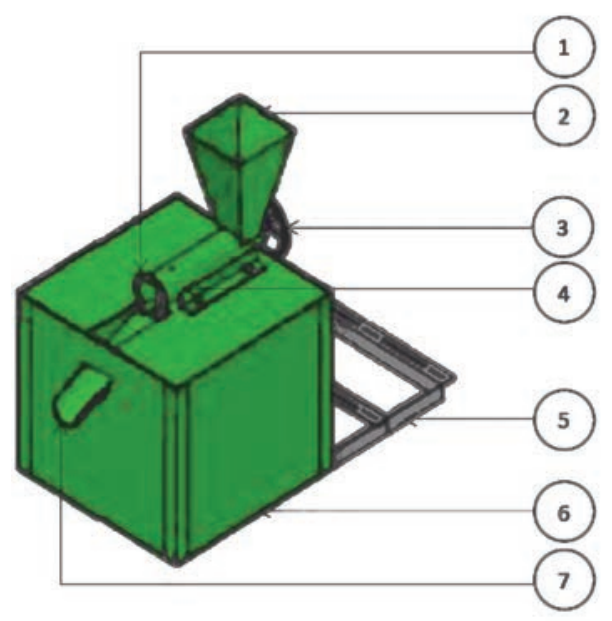

Figure 1. A biomass briquetting press (1-die-head, 2-hopper, 3-driven pulley, 4-barrel, 5-frame, 6-main housing, 7-collector). 
locally available materials for use in the production of the briquette (Figure 1). The design was carried out according to the approach and procedures reported for screw mixer (Fadeyibi et al., 2014; Fadeyibi et al., 2017). The press consists of a screw, which rotates tangentially inside a barrel, and is powered by a 2 HP single phase electric motor. When the non-woody herbaceous biomass materials are fed into the hopper, they are transported into the barrel by gravity. The materials are further pushed forward, by the conveying motion of the screw, towards the compression region. The biomass compaction occurs in the unit as the pressure build-up against the die head. Thus, the resulting products are collected as briquettes.

\section{Production of briquette}

Each of the 27 briquette blends (Table 2), were thoroughly mixed and passed into the briquetting press for processing. The machine was operated for $30 \mathrm{~min}$, and samples of the briquettes were formed and dried in an air circulated oven dryer for $24 \mathrm{~h}$ (Fadeyibi and Osunde, 2012). The moisture content of the samples at the end of the drying was found to be $4 \%$ (wet basis). Typical samples of the dried briquettes are shown in Figure 2.

\section{Performance evaluation}

\section{Determination of some physical properties of the briquettes}

The ash content was determined by placing $3 \mathrm{~g}$ of one of the briquette samples into a porcelain crucible with the help of a lid and heated to $750^{\circ} \mathrm{C}$ in an electric muffle oven (Model number: SX2-4$14 \mathrm{TP}, 1400^{\circ} \mathrm{C}$ heating rate). The final weight of the sample was determined using a precision balance (Model number: HPB 201) The difference between the initial weight of the sample and its weight after combustion, expressed as a percentage of the initial weight, represents the ash content (Ali et al., 2005). The bulk density of the briquette samples was determined using the method described by Jamradloedluk and Wiriyaumpaiwong (2007). The calorific value was determined as a function of the heat of reaction of the briquette samples in a benzoic acid solvent using the oxygen-bomb calorimeter (Model number: EN ISO 1716 ) (Musabbikhah et al., 2017). The burning rate was determined by taken instantaneous measurements of the relative mass of the briquette burning in every $10 \mathrm{sec}$. The tests were carried out for the other 26 briquette samples. Also, the procedures were repeated three times for each of the physical parameter and the average values were recorded.

\section{Determination of some mechanical properties of the briquettes}

A Universal Tensile Testing machine (Model number: M500, $100 \mathrm{AT}$ ), with loading range of $0-100 \mathrm{kN}$ and cross head speed of 10 $\mathrm{mm} . \mathrm{s}^{-1}$, was used for the compression analysis of each of the 27 briquette samples. The response of the samples to the force of compression at peak, break and yield were measured and recorded. The test was carried out at National Centre for Agricultural Mechanisation, Ilorin, Kwara State, Nigeria.

\section{Optimisation of briquette blending process}

\section{Optimisation framework}

The response of each of the briquette blends to the physical and mechanical properties of the briquette samples were analysed to determine the best possible combination of the blending process according to Eq. (1).

$y=f\left(x_{1}, x_{2}, x_{3}\right)$ where,

$y=$ response variable;

$x_{1}=$ agricultural residues $(\mathrm{kg})$;

$x_{2}=$ water $(\mathrm{kg})$;

$x_{3}=$ starch or binder $(\mathrm{kg})$.

The optimisation framework (Eq. 16) was solved subject to the conditions specified for the independent variable $(x)$, shown in Table 3.

\section{Experimental design}

A $3^{3}$ full factorial experiment was used to analyse the degree of experimental error associated with the differences in the level of treatment at $\mathrm{P}<0.05$. A Box-Bekhen Design Methodology, which

Table 2. Briquette blends.

\begin{tabular}{|c|c|c|c|}
\hline$s / n$ & Binder (kg) & Water (kg) & Residue (kg) \\
\hline 1 & 0.30 & 0.02 & 0.32 \\
\hline 2 & 0.30 & 0.02 & 0.34 \\
\hline 3 & 0.30 & 0.02 & 0.36 \\
\hline 4 & 0.30 & 0.03 & 0.32 \\
\hline 5 & 0.30 & 0.03 & 0.34 \\
\hline 6 & 0.30 & 0.03 & 0.36 \\
\hline 7 & 0.30 & 0.04 & 0.32 \\
\hline 8 & 0.30 & 0.04 & 0.34 \\
\hline 9 & 0.30 & 0.04 & 0.36 \\
\hline 10 & 0.35 & 0.02 & 0.32 \\
\hline 11 & 0.35 & 0.02 & 0.34 \\
\hline 12 & 0.35 & 0.02 & 0.36 \\
\hline 13 & 0.35 & 0.03 & 0.32 \\
\hline 14 & 0.35 & 0.03 & 0.34 \\
\hline 15 & 0.35 & 0.03 & 0.36 \\
\hline 16 & 0.35 & 0.04 & 0.32 \\
\hline 17 & 0.35 & 0.04 & 0.34 \\
\hline 18 & 0.35 & 0.04 & 0.36 \\
\hline 19 & 0.40 & 0.02 & 0.32 \\
\hline 20 & 0.40 & 0.02 & 0.34 \\
\hline 21 & 0.40 & 0.02 & 0.36 \\
\hline 22 & 0.40 & 0.03 & 0.32 \\
\hline 23 & 0.40 & 0.03 & 0.34 \\
\hline 24 & 0.40 & 0.03 & 0.36 \\
\hline 25 & 0.40 & 0.04 & 0.32 \\
\hline 26 & 0.40 & 0.04 & 0.34 \\
\hline 27 & 0.40 & 0.04 & 0.36 \\
\hline
\end{tabular}

Table 3. Properties of the optimisation variables in a Box-Bekhen Design protocol.

\begin{tabular}{lccccc} 
& \multicolumn{7}{c}{ Allowable range } \\
Optimisation variable & Unit & -1 & 0 & +1 & Constraint \\
Binder & $\mathrm{kg}$ & 0.30 & 0.35 & 0.40 & $-1<\alpha \leq 1$ \\
Water & $\mathrm{kg}$ & 0.02 & 0.03 & 0.04 & $-1<\alpha \leq 1$ \\
\hline Residue & $\mathrm{kg}$ & 0.32 & 0.34 & 0.36 & $-1<\alpha \leq 1$ \\
\hline
\end{tabular}


allows the use of three variables at three levels, was used to determine the optimum blends for the best briquette formulation found closer to the optimal goal. Table 4 shows the layout of the 17 possible experiments with 5 centre points per block. Also, a one-way t-test approach was used to compare the energy values of the briquettes produced with that of the wood charcoal using Eq. (2). The population calorific mean and the sample calorific mean values of the briquette samples were compared hypothetically at $\mathrm{P}<0.05$.

$$
t=\frac{\mu-M_{o}}{\sqrt{S_{d} / n}}
$$

where:

$\mu=$ Population calorific mean value $\left(\mathrm{kcal}^{\mathrm{kg}} \mathrm{kg}^{-1}\right)$;

$\mathrm{M}_{0}=$ Sample calorific mean value $\left(\mathrm{kcal} . \mathrm{kg}^{-1}\right)$;

$\mathrm{S}_{\mathrm{d}}=$ Standard deviation of the energy value $\left(\mathrm{kcal}^{\mathrm{kg}} \mathrm{kg}^{-1}\right)$;

$\mathrm{n}=$ number of sample replicates.

\section{Results and discussion}

\section{Effect of starch binder and residue on briquette properties}

The effects of binding agent and residue on the physical properties of the briquettes are shown in Figure 3A-D and 4A. Irrespective of the nature of the agricultural residue, it can be seen from Figure 3A that the calorific value increased from 2500-4350 kcal. $\mathrm{kg}^{-1}$, with an increase in the weight of the binder and a decrease in the water content. The calorific value is an important term of any briquetting and this variation is same for all the briquettes prepared from the three agricultural residues. When plant residues are utilised as a fastener or binder with the different biomass materials, it can potentially enhance the calorific value. A similar result was reported by Roy and da Silva (2014) who demonstrated that briquettes delivered by utilising the sustain stocks and cow dung waste has an energy value of 5920.40 kcal. $\mathrm{kg}^{-1}$ higher than the different briquettes utilised paper mash. The burning or combustion time of the briquette increased from 4$10 \mathrm{~min}$, with an increase in the weight of the binder and a decrease in water content (Figure 3B). Studies have shown that the binder has an observable impact on biomass briquette forming and

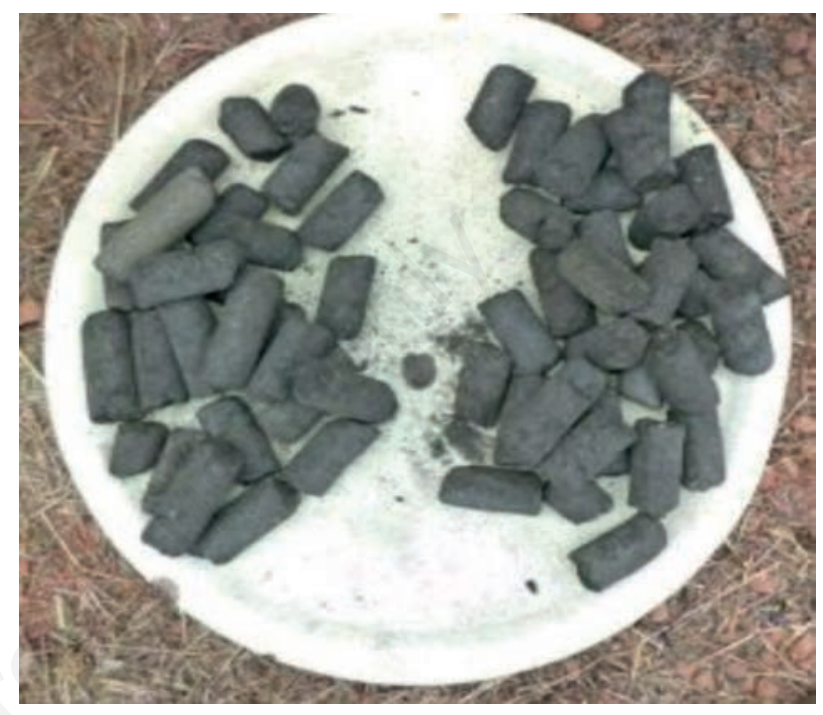

Figure 2. Samples of Briquettes produced.

Table 4. Layout of the experiment for optimisation.

\begin{tabular}{|c|c|c|c|c|c|c|c|c|c|c|c|}
\hline$n r$ & S & W & $\mathbf{R}$ & $\begin{array}{r}\text { Re } \\
\text { Comb time } \\
\text { (min) }\end{array}$ & $\begin{array}{c}\text { Sponse variab } \\
\text { Ash content } \\
(\%)\end{array}$ & $\begin{array}{l}\text { Moisture content } \\
(\%)\end{array}$ & $\begin{array}{l}\text { Breaking force } \\
\text { (N) }\end{array}$ & $\begin{array}{l}\text { Peak force } \\
\text { (N) }\end{array}$ & $\begin{array}{l}\text { Yield force } \\
\qquad(\mathrm{N})\end{array}$ & $\begin{array}{l}\text { Bulk density } \\
\left(\mathrm{kg} \mathrm{m}^{-3}\right)\end{array}$ & $\begin{array}{c}\text { Calorific value } \\
\left.\text { (kcal. } \mathbf{k g}^{-1}\right)\end{array}$ \\
\hline 1 & 0.35 & 0.03 & 0.34 & 11.50 & 0.34 & 4.00 & 1414 & 280.0 & 1310 & 250 & 2817.1 \\
\hline 2 & 0.30 & 0.03 & 0.32 & 11.50 & 0.33 & 3.78 & 1265 & 2055 & 1199 & 260 & 3786.2 \\
\hline 3 & 0.30 & 0.03 & 0.36 & 11.55 & 0.33 & 2.88 & 1077 & 1313 & 1037 & 270 & 4123.1 \\
\hline 4 & 0.35 & 0.03 & 0.34 & 11.80 & 0.36 & 4.23 & 1324 & 1816 & 1124 & 290 & 2761.5 \\
\hline 5 & 0.35 & 0.03 & 0.34 & 11.95 & 0.35 & 6.17 & 1223 & 2080 & 1354 & 330 & 3483.2 \\
\hline 6 & 0.30 & 0.02 & 0.34 & 12.30 & 0.38 & 4.00 & 1254 & 1590 & 1332 & 360 & 4002.3 \\
\hline 7 & 0.40 & 0.04 & 0.34 & 11.35 & 0.36 & 3.90 & 1243 & 1397 & 1243 & 390 & 3679.9 \\
\hline 8 & 0.35 & 0.03 & 0.34 & 11.40 & 0.35 & 5.10 & 1123 & 1225 & 1123 & 430 & 3934.3 \\
\hline 9 & 0.30 & 0.04 & 0.34 & 11.00 & 0.37 & 4.82 & 1123 & 1397 & 1222 & 460 & 4711.7 \\
\hline 10 & 0.40 & 0.03 & 0.36 & 7.500 & 0.39 & 3.67 & 1393 & 1225 & 1074 & 210 & 3721.7 \\
\hline 11 & 0.35 & 0.03 & 0.34 & 7.550 & 0.33 & 2.99 & 1698 & 2898 & 1698 & 220 & 3891.3 \\
\hline 12 & 0.35 & 0.04 & 0.36 & 7.700 & 0.33 & 4.34 & 1329 & 1284 & 1329 & 230 & 3680.0 \\
\hline 13 & 0.40 & 0.03 & 0.32 & 6.000 & 0.31 & 2.78 & 1221 & 1798 & 1232 & 240 & 2780.2 \\
\hline 14 & 0.40 & 0.02 & 0.34 & 5.800 & 0.32 & 4.23 & 1321 & 1529 & 1423 & 250 & 2594.2 \\
\hline 15 & 0.35 & 0.02 & 0.36 & 5.800 & 0.33 & 5.23 & 1432 & 1432 & 1333 & 260 & 3764.3 \\
\hline 16 & 0.35 & 0.02 & 0.32 & 7.000 & 0.32 & 4.00 & 1112 & 1432 & 1332 & 270 & 3494.3 \\
\hline 17 & 0.35 & 0.04 & 0.32 & 8.400 & 0.32 & 3.56 & 1213 & 1423 & 1223 & 280 & 2561.7 \\
\hline
\end{tabular}

$\mathrm{R}$, residue $(\mathrm{kg}) ; \mathrm{S}$, starch $(\mathrm{kg})$; W, water $(\mathrm{kg})$; nr, number of runs. 
mechanical properties (Karunanithy et al., 2012). The bulk density varied only slightly from $200-275 \mathrm{~kg} \mathrm{~m}^{-3}$, with an increase in both the weight of the binder and the water content (Figure 3C). The ash content of the briquettes decreased from $0.37-0.26 \mathrm{~kg}$, with an increase in the weight of water but increases, with an increase in the weight of the binder (Figure 3D). A related research by Roy and da Silva (2014) reported that the ash content of briquettes prepared from groundnut shells was less compared with that prepared using the dairy animal manure.

The relationships between the binding agent and residue on the load at peak, break and yield of the briquettes are shown in Figure $4 \mathrm{~A}$ to $\mathrm{D}$. It can be seen from Figure $4 \mathrm{~A}$, that the compressive force at peak increases with weight of water and binder from 0-1500 N. However, the compressive forces at break and yield varied only slightly with an increase in the weight of the moisture and the binder (Figure 4B and C). Özkaya et al. (2018) reported that the briquette hardness can be enhanced with the addition rice bran binder. Also, the nature of briquette constituents play important role in the mechanical behaviour of the briquette products. Briquette hardness, for example, is mainly influenced by its particle size distribution. Generally, the finer the particle size, the greater will be the hardness and hence the compressive forces at peak, break and yield. Fine particles usually absorb more moisture than their coarse counterpart and, therefore, undergo a higher degree of conditioning (Kaliyan and Morey, 2009). The bulk density increases with an increase in the weight of the compacted constitutes of the briquettes, as was shown in Figure 3C. It is the ratio of the total weight of the materials compacted to the total volume of the briquetting vessel. This provides an underlying effect on the hardness of the product as more and more the residue and binding agent are added in the briquette production process. These findings agree with the previous work by Ryu et al. (2005), whose study revealed that the particle size influenced the density of briquettes since smaller particles resulted in more dense packing of particles at constant pressure. This study is essential to understand the behaviour of the briquette product, especially during packaging
A

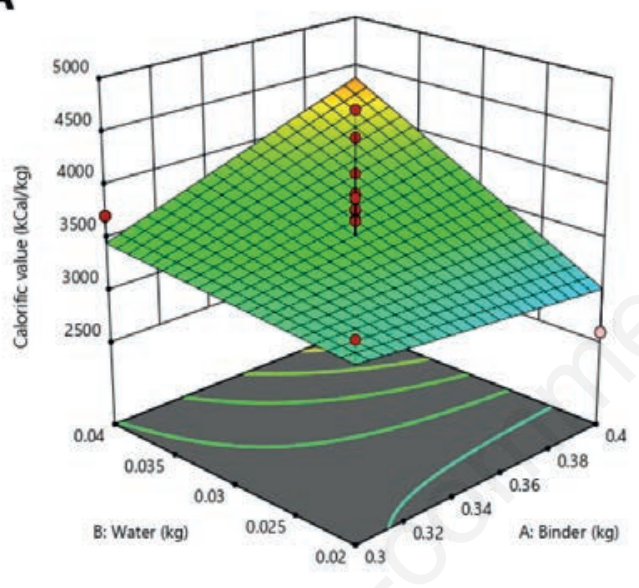

C

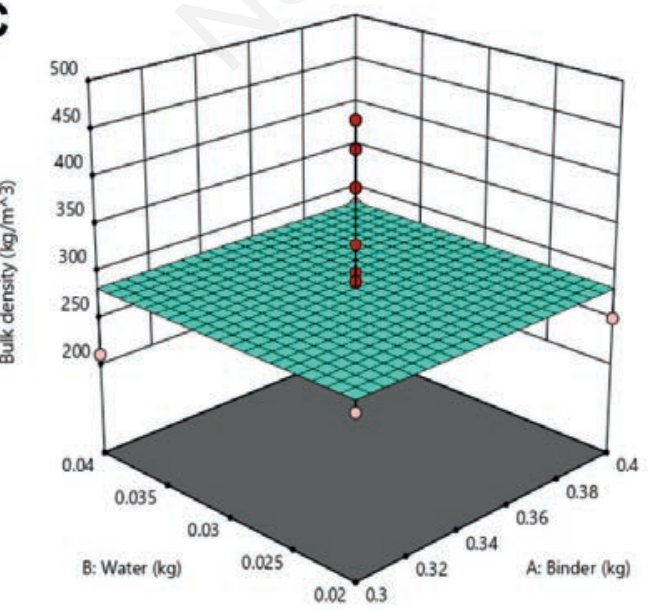

B

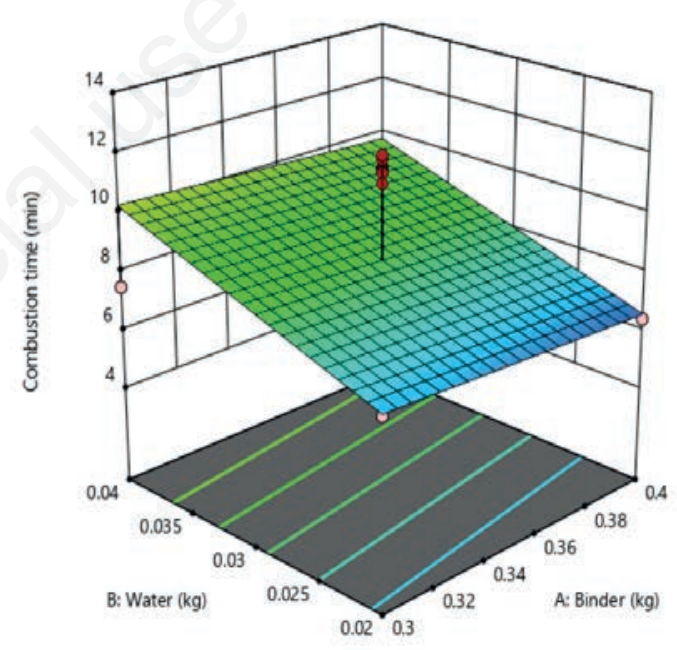

D

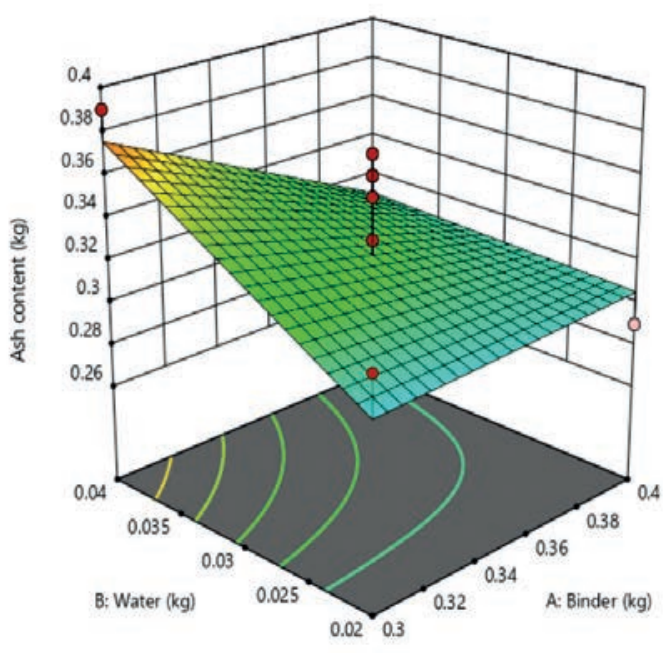

Figure 3. A) Effect of binder and water on calorific value; B) Effect of binder and water on combustion time; C) Effect of binder and water on bulk density; D) Effect of binder and water on ash content. 
and transportation on rough roads.

Furthermore, the outcomes of experiments by Jamradloedluk and Wiriyaumpaiwong (2007) showed that briquettes produced using charcoal tidy and different biomass materials with starch mixes were best in physical qualities. The briquettes produced using charcoal tidy with bovine manure blends were observed to be most noteworthy in deformation as the results of the applied load. The effects of starch binder, water and the different biomass residues have been reported to enhance the surface smoothness of briquettes (Oladeji and Enweremadu, 2012). However, the difference in the particle size improves the packing factor, density and static strength of the briquette. The results of the effect of deformation on the applied load revealed that mixture of the biomass residues and starch are good blends for quality briquettes. The briquette can also be able to withstand any likely vibration resulting from transportation on rough roads.

\section{Optimum briquette blend for alternative energy appli- cation}

The purpose of optimisation is to obtain briquettes that can sufficiently withstand mechanical damage, especially during transportation, and to produce briquette with ideal physical characteristics. The optimum process variable of the ideal briquette blend is shown Figure 5. The goal of the optimisation variables is indicated by the axis, which showed the range of the values of the binder, water and residue. It was desired to maximize the calorific value, combustion time and bulk density, whereas the ash content, moisture content, force at peak, break and yield are minimized. The optimum briquette blend has a composition of $0.399 \mathrm{~kg}$ binder, $0.03 \mathrm{~kg}$ water and $0.33 \mathrm{~kg}$ residue. The responses of the ideal briquette blend, to its overall acceptability closer to the optimum goal, were found to be $4711.87 \mathrm{kcal}_{\mathrm{.kg}}{ }^{-1}$ calorific value, $9.846 \mathrm{~min}$ combustion time, $282.59 \mathrm{kgm}^{-3}$ bulk density, $0.308 \mathrm{~kg}$ ash content, $5.11 \%$ moisture content, $1462.02 \mathrm{~N}$ force at peak, $1355.22 \mathrm{~N}$ force at break and $1293.85 \mathrm{~N}$ force at yield with a desirability index of $61.5 \%$. This is in line with the research results obtained by Kaur et al. (2017). In other related investigation, Pereira et al. (2012) studied the quality of wood and charcoal from eucalyptus clones for Ironmaster use and reported an average $0.5 \mathrm{~kg}$ ash content, 31.5 MJ kg-1 calorific value, $0.4 \mathrm{~g} \mathrm{~cm}^{-3}$ bulk density of wood charcoal. Also, Sotannde et al. (2015) studied the physical and combustion properties of charcoal briquettes from neem wood residues and reported an average of $0.4 \mathrm{~kg}$ ash content, $32.09 \mathrm{MJ} \mathrm{kg}^{-1}$ calorific value of the charcoal. A comparison of the properties of the ideal briquette blend obtained in the present investigation with the properties of the wood charcoal indicates no significant difference $(\mathrm{P}<0.05)$. Thus, this may imply that the briquette obtained from the optimum blend can be used as an alternative source of cooking energy in rural communities.
A

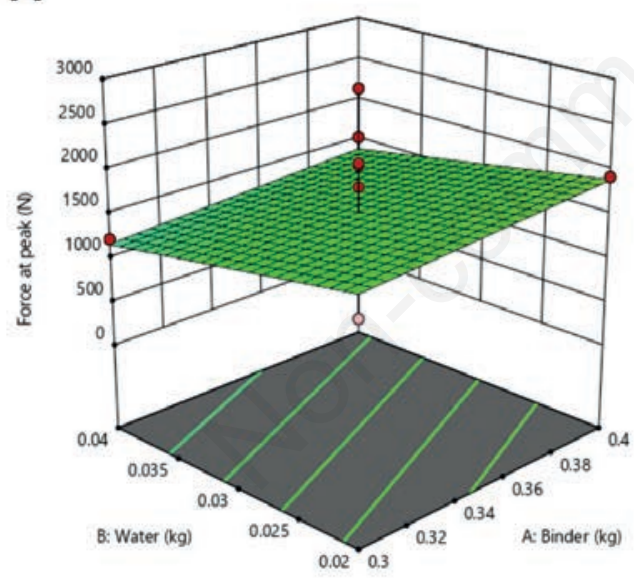

C

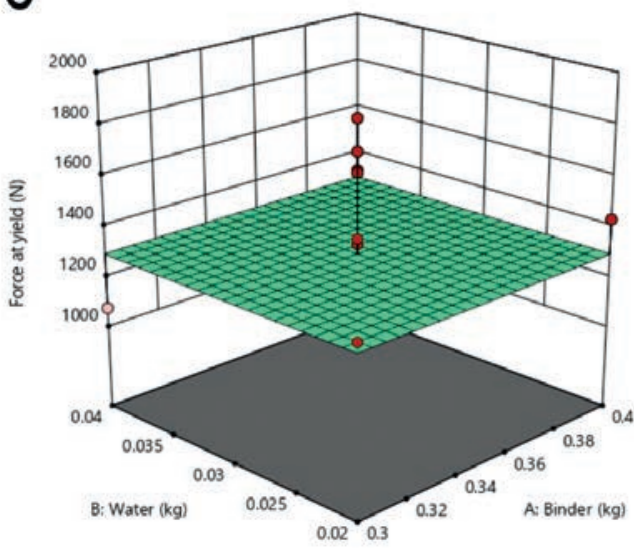

B

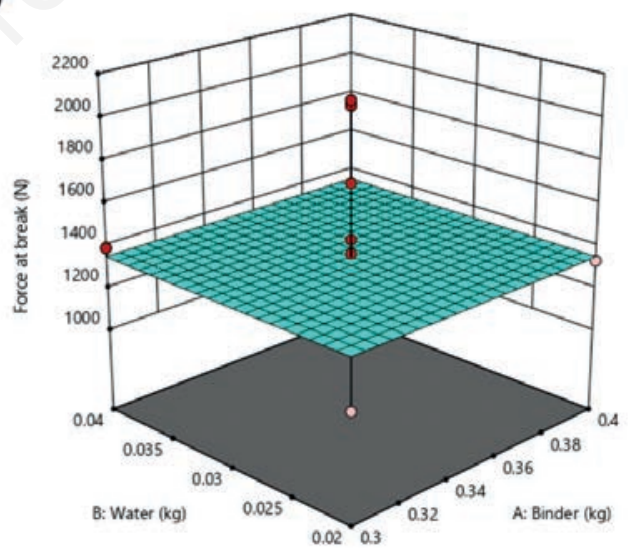

Figure 4. A) Effect of binder and water on force at peak; B) Effect of binder and water on force at break; C) Effect of binder and water on force at yield. 

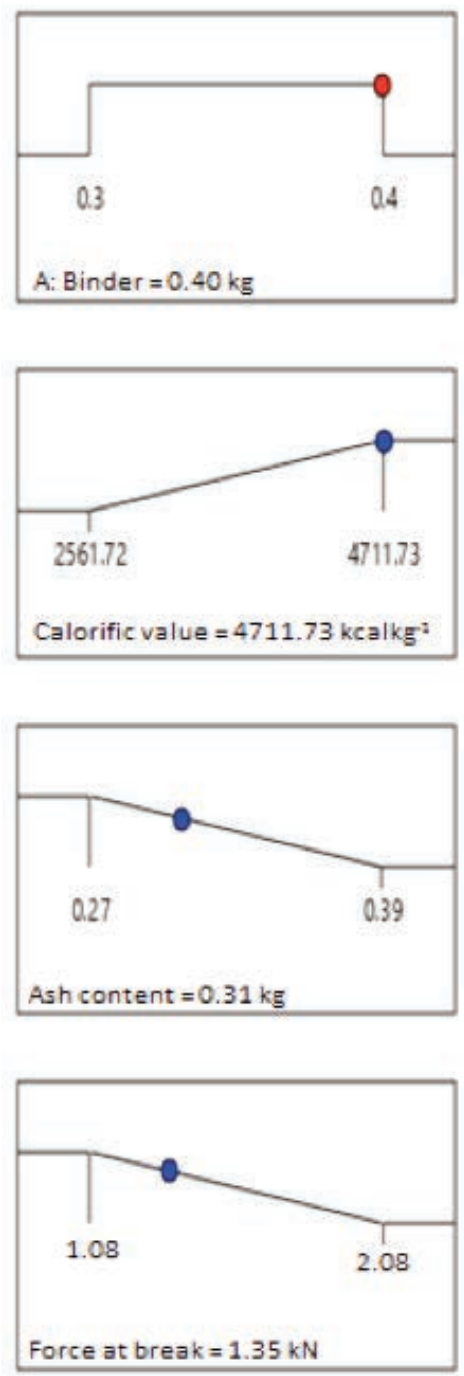
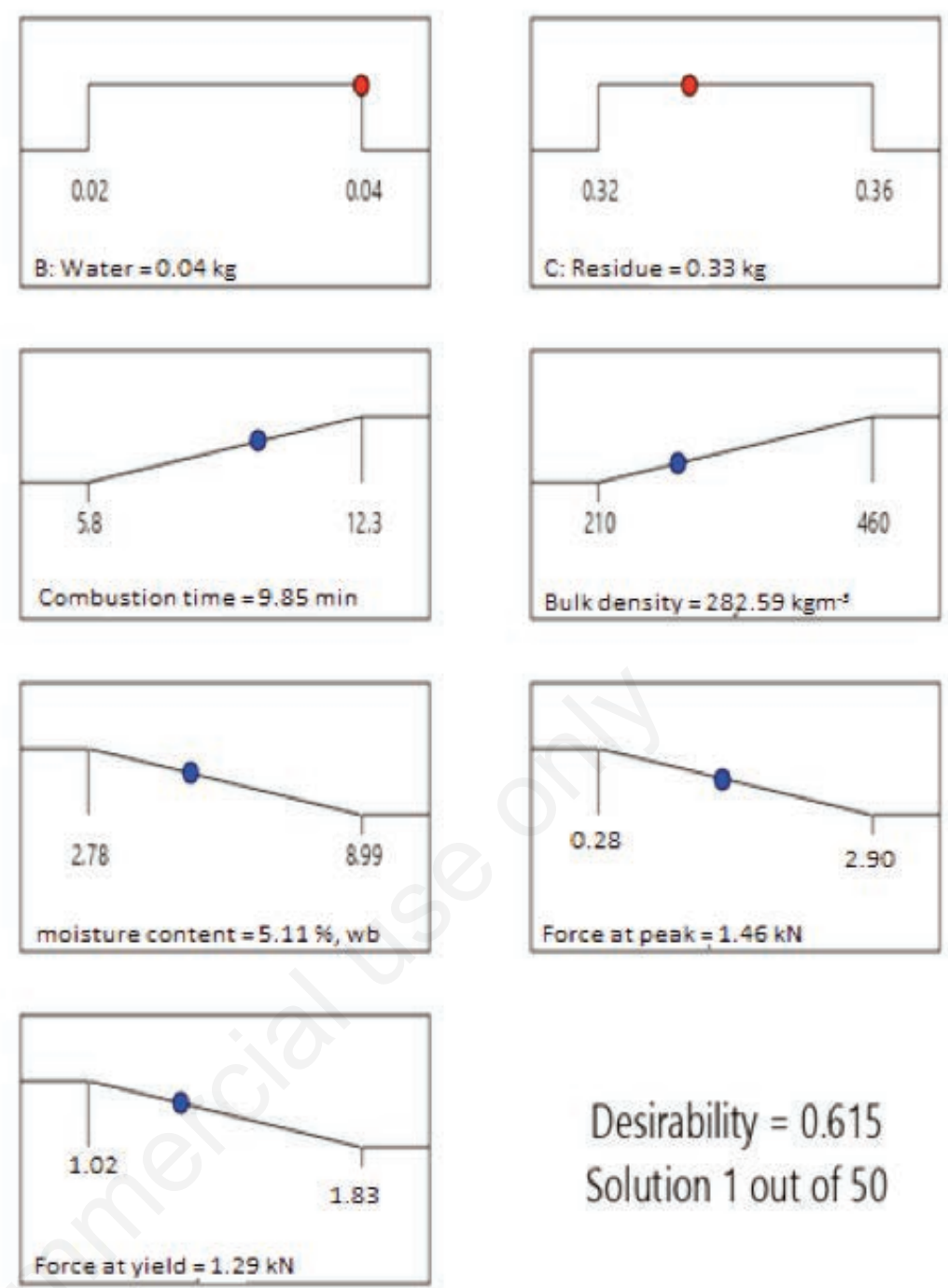

Force at peak $=1.46 \mathrm{kN}$

\section{Desirability $=0.615$ \\ Solution 1 out of 50}

Figure 5. Briquette process variable closer to optimum goal.

\section{Conclusions}

Biomass briquette can potentially serve as an alternative to wood charcoal because of their close energy value. This paper reports the development of briquette samples from the mixtures of $0.32-0.39 \mathrm{~kg}$ of each of the carbonised agricultural residues (jatropha shells, groundnut shell and melon seed shell), $0.30-0.40 \mathrm{~kg}$ of starch of cassava starch and $0.020-0.04 \mathrm{~kg}$ of water. The optimum briquette blend was formulated with $0.33 \mathrm{~kg}$ of residue, $0.399 \mathrm{~kg}$ of starch binder and $0.03 \mathrm{~kg}$ of water. This blend gave values of $4711.87 \mathrm{kcal}^{\mathrm{kg}}{ }^{-1}, 9.846 \mathrm{~min}, 282.59 \mathrm{~kg} \mathrm{~m}^{-1}, 0.308 \mathrm{~kg}$, $5.11 \%, 1462.02 \mathrm{~N}, 1355.22 \mathrm{~N}$ and $1293.85 \mathrm{~N}$ for caloric value, combustion time, bulk density, ash content, moisture content, force at peak, force at break and force at yield, respectively, with a desirability index of $61.5 \%$. A comparison of the properties of the ideal briquette blend obtained in the present investigation with the properties of the wood charcoal indicates no significant difference $(\mathrm{P}<0.05)$. Thus, this may imply that the resulting briquette can be used as an alternative source of cooking energy in the rural communities.

\section{References}

Adam J.C. 2009. Improved and more environmentally friendly charcoal production system using a low-cost retort-kiln (Ecocharcoal). Renew. Energy 34:1923-5.

Ahiduzzaman M. 2007. Rice husk energy technologies in Bangladesh. Agricultural Engineering International: the CIGR Ejournal. Invited Overview No. 1. Vol. IX. January, 2007.

Ali M.F., Ali E.B.M., Speight J.G. 2005. Handbook of industrial chemistry. McGraw-Hill Companies, New York, NY, USA.

Antal M.J., Grønli M. 2003. The art, science, and technology of charcoal production. Industr. Engine. Chem. Res. 42:1619-40.

Ben-Iwo J., Manovic V., Longhurst P. 2016. Biomass resources and biofuels potential for the production of transportation fuels in Nigeria. Renew. Sustain. Energy Rev. 63:172-92.

Bhattacharya S.C., Leon M.A., Rahman M.M. 2002. A study on improved biomass briquetting. Energy Sustain. Develop. 6:67-71.

Boersema J.J. 2009. Environmental sciences, sustainability, and quality. In: Principles of environmental sciences. Springer, Dordrecht, the Netherlands, pp. 3-14 
Da Costa J.L., Navarro A., Neves J.B., Martin M. 2004. Household wood and charcoal smoke increases risk of otitis media in childhood in Maputo. Int. J. Epidemiol. 33:573-8.

Oladeji J.T., Enweremadu C.C. 2012. The effects of some processing parameters on physical and densification characteristics of corncob briquettes. Int. J. Energy Engine. 2:22-7.

Fadeyibi A., Osunde Z.D., Agidi G., Evans E. C. 2014. Flow and strength properties of cassava and yam starch-glycerol composites essential in the design of handling equipment for granular solids. J. Food Engine. 129:38-46.

Fadeyibi A., Osunde Z.D., Agidi G., Egwim E.C. 2016. Design of single screw extruder for homogenizing bulk solids. Agricultural Engineering International: CIGR Journal 18:4.

Fadeyibi A., Osunde Z.D., Yisa M.G. 2017. Effects of glycerol and diameter of holes in breaker plate on performance of a screw mixer for nanocomposites. Agric. Engine. 21:15-26.

Fadeyibi A., Osunde Z.D. 2012. Thermo-physical properties of rubber seed useful in the design of storage structure. Int. J. Agric. Biol. Engine. 5:62-6.

Grella M., Manzone M., Gioelli F., Balsari P. 2013. Harvesting orchard pruning residues in southern Piedmont: A first evaluation of biomass production and harvest loss. J. Agricult. Engine. 44:e14, 97-102.

Helwani Z., Fatra W., Arifin L., Othman M.R. 2018. Effect of process variables on the calorific value and compressive strength of the briquettes made from high moisture Empty Fruit Bunches (EFB). In: IOP Conference Series: Materials Science and Engineering. IOP Publishing, 345(1):012020.

Höök M., Tang X. 2013. Depletion of fossil fuels and anthropogenic climate change - A review. Energy Policy 52:797-809.

ISO E. 2014. 17225-2: 2014 - Solid Biofuels - Fuel Specifications and Classes Part 2: Graded Wood Pellets. The British Standards Institution, London, UK.

Jamradloedluk J., Wiriyaumpaiwong S. 2007. Production and characterisation of rice husk based charcoal briquettes. Engine. Appl. Sci. Res. 34:391-8.

Kaliyan N., Morey R.V. 2009. Factors affecting strength and durability of densified biomass products. Biomass Bioener. 33:337-59.

Karunanithy C., Wang Y., Muthukumarappan K., Pugalendhi S.
2012. Physiochemical characterisation of briquettes made from different feedstocks. Biotechnol. Res. Int. 2012:165202, $1-12$.

Kaur A., Kumar A., Singh P., Kundu K. 2017. Production, analysis and optimisation of low cost briquettes from biomass residues. Adv. Res. 12:1-10.

Lucchini P., Quilliam R.S., DeLuca T.H., Vamerali T., Jones D.L. 2014. Increased bioavailability of metals in two contrasting agricultural soils treated with waste wood-derived biochar and ash. Environ. Sci. Pollut Res. 21:3230-40.

Roy M.M., Da Silva A.F. 2014. An alternative use of crude glycerin in canadian wood pellet industry. Int. J. Mechan. Mechatron. Engine. 14:23-34.

Musabbikhah M., Saptoadi H., Subarmono S., Wibisono M.A., 2017. Modelling and optimisation the best parameters of rice husk drying and carbonisation using taguchi method with multi response signal to noise procedure. Int. J. Renew. Energy Res. (IJRER) 7:1219-27.

Ndindeng S.A., Mbassi J.E.G., Mbacham W.F., Manful J., Graham-Acquaah S., Moreira J., Dossou J., Futakuchi K. 2015. Quality optimisation in briquettes made from rice milling by-products. Energy Sustain. Develop. 29:24-31.

Özkaya B., Baumgartner B., Özkaya H. 2018. Effects of concentrated and dephytinized wheat bran and rice bran addition on bread properties. J. Texture Stud. 49:84-93.

Pereira B.L., Costa Oliveira A., Carvalho A.M.M.L., Carneiro A.O., Santos L.C., Vital B.R. 2012. Quality of wood and charcoal from eucalyptus clones for ironmaster use. Int. J. Forest. Res. 2012:523025, 1-8.

Ryu C., Yang Y.B., Khor A., Yates N.E., Sharifi V.N., Swithenbank J. 2006. Effect of fuel properties on biomass combustion: Part I. Experiments - fuel type, equivalence ratio and particle size. Fuel 85:1039-46.

Sotannde O.A., Oluyege A.O., Abah G.B. 2010. Physical and combustion properties of charcoal briquettes from neem wood residues. Int. Agrophys. 24:189-94.

Thoreson C.P., Webster K.E., Darr M.J., Kapler E.J. 2014. Investigation of process variables in the densification of corn stover Briquettes. Energies 7:4019-32. 